renowned for philanthropy, and that the immense costs of litigation prevented all but the wealthy from seeking redress through the courts.

She argued that a radical review of the law and practice relating to compensation was long overdue and that some countries such as Sweden had effective ways of paying compensation that were popular with doctors and patients. Ms Sinclair then followed with more energetic criticisms of the present system.

Less than half of the population are eligible for legal aid, which, even if awarded, may have to be repaid from damages if the case is successful. Those who are aggrieved by the application of some part of the Mental Health Act face an additional hurdle in having to obtain the permission of the High Court before civil proceedings may start. (MHA 1983, section 139). She also maintained that the defence societies were tardy in dealing with claims, and that individual doctors were slow to apologise when errors had occurred. The audience were sympathetic to these views while mindful that a small minority of patients were truly 'vexatious litigants'.

A trainee then enquired if hospital staff were justified in refusing to care for a psychotic patient who was in a high risk group for HIV infection, yet unable to agree to the relevant test. The panel were unable to support this view and it was suggested that such patients should be treated as if they were positive. This was all very well, remarked one of the audience, but if that patient had sexual intercourse with a female patient, what then should the staff do? Any response would seem to lead to a breach of confidentiality. While the panel agreed that some problems did not have easy ethical solutions, Mrs Brahams argued that AIDS should be dealt with like many other serious illnesses, and that persistent lobbying of some minority groups led to anomalous medical responses. On a related issue, we were reminded that the refusal of the prison service to sanction the issue of condoms to prisoners would certainly lead to the spread of HIV-related illnesses in Britain's jails.

Exercising the chairman's prerogative, I then asked if the panel were concerned at the practice of some psychiatrists who offered public diagnoses on the mental states of offenders and world leaders. For example, a slip of the tongue by President Reagan is seen as a sign of dementia; turning to this country, some very ill-advised comments were made after the Hungerford tragedy. Such statements were regarded by the panel as thoroughly reprehensible and most unprofessional. Dr Bradley gave a reminder that it is difficult enough to comment on the mental state of the person in front of you, let alone someone you have not examined.

On that note the forum ended. The panel adjourned to the bar of the RSM and agreed that by comparison to the tedium of stand-up speeches the Question Time format had fostered a lively debate. On behalf of the Collegiate Trainees' Committee may I thank Mrs Diana Brahams, Ms Lydia Sinclair, Dr John Bradley and Dr Garth Hill for contributing to the success of the session.

\title{
Autumn Quarterly Meeting
}

Kensington Town Hall, Hornton Street,
London W8, 26 and 27 October 1988

\section{Registration}

Would members please note that due to the postal strike they may not receive their Autumn Quarterly Meeting programmes in time to register by 7 October 1988. Members are therefore advised either to register on arrival at the meeting or to ring Deborah Hart at the College before the meeting. The daily registration fee for members is $£ 17.50$ and for inceptors $£ 12.00$ only. The outline of the programme is as follows: Wednesday, 26 October 1988 WHO (to celebrate its 40th anniversary); Psychiatry in the Private Sector; Interface between Neurology and Psychiatry; The
Maudsley Lecture (to be presented by Professor E. S. Paykel at $1.45 \mathrm{pm}$ ); Negative Symptoms in Schizophrenia; Adolescent Psychiatry - Is It Necessary?; Short papers and poster presentations.

Thursday, 27 October 1988 Location of the Schizophrenia Gene; Psychotherapy in In-patient Settings; Short papers and poster presentations; Is Community Care Working? The Evidence; Treatment and Prevention of Post-Natal Depression.

Note Professor Brice Pitt will be taking over the responsibilities of the College's Public Education Programme from Dr C. M. B. Pare as from 1 December 1988. Those members of the College who have agreed to be included on the College's 'experts' list are invited to a buffet luncheon to be held on 26 October 1988 at $12.30 \mathrm{pm}$ at Kensington Town Hall. 